\title{
PENDETEKSIAN KECURANGAN LAPORAN KEUANGAN DENGAN BENISH M-SCORE PADA PERUSAHAAN YANG TERDAFTAR DI BURSA EFEK INDONESIA
}

\author{
Amerti Irvin Widowati ${ }^{1}$ \\ Linda Ayu Oktoriza ${ }^{2}$
}

amerti@usm.ac.id ${ }^{1}$

\section{Fakultas Ekonomi Universitas Semarang}

Diterima : November 2020, Disetujui : Desember 2020, Dipublikasikan: Januari 2021

\begin{abstract}
The Beneish M-Score is a financial statement analysis technique that can be applied to detect fraudulent financial statements in the form of earnings overstatement manipulation. This statement has been answered by Messod D. Beneish, a professor at Indiana University who conducted research on quantitative differences between companies identified as having manipulated earnings and companies identified as not manipulating earnings.

The object of this research is a company that produces raw materials and manufactures listed on the IDX in 2019. There are 178 companies that were sampled in this study. The sampling technique used non-probability-purposive judgment sampling. The data collection method uses the documentation method. Methods of data analysis with quantitative descriptive using the ratio proposed by Messod D. Benish. There are 5 measurement variables, namely Days' Sales In Receivables Index (DSRI), Gross Margin Index (GMI), Asset Quality Index (AQI), Sales Growth Index (SGI), and Total Accrual To Total Assets Index (TATA).

The results of this study were: 1) there were 2 companies that were stunned by manipulators as indicated by being in the manipulator category in 3 of the 5 measured categories; 2) while others are included in the category of Non manipulator and Gray company.

Keywords: Beneish M-Score, Finansial Reporting.
\end{abstract}

\begin{abstract}
ABSTRAK
Beneish M-Score adalah suatu teknik analisis laporan keuangan dapat dit-erapkan untuk mendeteksi kecurangan laporan keuangan berupa manipulasi laba earning overstatement. Pernyataan ini telah dijawab oleh Messod D. Beneish, seorang profesor di Indiana University yang melakukan penelitian atas perbedaan kuantitaif antara perusahaan yang teridentifikasi telah melakukan manipulasi laba dan perusahaan yang teridentifikasi tidak melakukan manipulasi laba.

Objek penelitian ini adalah perusahaan sektor Penghasil bahan baku dan manufaktur yang terdaftar di BEI tahun 2019. Terdapat 178 perusahaan yang menjadi sampel pada penelitian ini. Teknik penentuan sampel menggunakan non probability-purposive judgement sampling. Metode pengumpulan data menggunakan metode dokumentasi. Metode analisis data dengan deskriptif
\end{abstract}


kuantitatif menggunakan rasio yang dikemukakan oleh Messod D.Beneish. Terdapat 5 variabel pengukuran yaitu Days' Sales In Receivables Index (DSRI), Gross Margin Index (GMI), Asset Quality Index (AQI), Sales Growth Index (SGI), dan Total Accrual To Total Assets Index (TATA).

Hasil dari penelitian ini adalah: 1) terdapat 2 perusahaan yang tergoLong manipulator yang ditunjukkan dengan masuk kategori manipulator pada 3 kategori dari 5 kategori yang diukur; 2)sedangkan lainnya termasuk dalam kategori Non manipulator dan Grey company.

Kata kunci: Beneish M-Score, Laporan keuangan

\section{PENDAHULUAN}

Setiap perusahaan mempunyai laporan keuangan yang bertujuan menyediakan informasi yang menyangkut posisi keuangan, kinerja serta perubahan posisi keuangan suatu perusahaan yang bermanfaat bagi sejumlah besar pemakai laporan keuangan dalam pengambilan keputusan secara ekonomi. Laporan keuangan harus disiapkan secara periodik untuk pihak-pihak yang berkepentingan. Laporan keuangan memberikan informasi keuangan suatu perusahaan yang dapat digunakan dalam pengambilan keputusan ekonomi serta menunjukkan kinerja yg telah dilakukan manajemen (stewardship) atau pertanggungjawaban manajemen atas penggunaan sumber-sumber daya yg dipercayakan kepadanya.

Laporan keuangan merupakan instrumen yang sangat penting bagi suatu entitas yang digunakan sebagai alat komunikasi antara data keuangan dengan pihak-pihak pengguna lapran keuangan. Menurut PSAK No. 1 (2015), menyatakan bahwa tujuan laporan keuangan adalah untuk memberikan informasi mengenai posisi keuangan, kinerja keuangan dan arus kas entitas yang bermanfaat bagi sebagian besar kalangan pengguna laproan dalam pembuatan keputusan ekonomi. Menyadari pentingnya kandungan informasi dalam laporan keuangan tidak menutup kemungkinan dapat terjadi salah saji baik dikarenakan kekeliruan atau kecurangan oleh perilaku manajer perusahaan. Dampak yang timbul dari adanya kecurangan laporan keuangan adalah dapat mengurangi tingkat kepercayaan dan merugikan para pemangku kepentingan seperti kreditor, investor, karyawan, dan juga pemerintah (Christy \& Stephanus, 2018) .

Kecurangan laporan keuangan merupakan tindakan manipulasi terhadap isi laporan keuangan dengan tujuan untuk mendapatkan keuantungan secara pribadi. Kecurangan laporan keuangan merupakan salah satu bagian dari tiga jenis kecurangan yang ada. berdasarkan Report To The Nation Association of Certified Fraud Examiners (2016), terdapat tiga jenis kasus kecurangan yang menjadi perhatian global yaitu asset Misappropriation, Corruption dan Financial Statement Fraud. Dalam survai global yang dilakukan oleh ACFE (2016), menyatakan bahwa kasus Asset Misappropriation merupakan kasus kecurangan terbesar dengan persentase sebesar 83,5\% dari jumlah kasus lebih dari 83\%. Korupsi menempati posisi kedua setelah Asset Misappropriationdengan persentase sebesar 35,4\%. Financial Statement Fraud mendapatkan persentase sebesar 9,6\%. Meskipun Financial Statement Fraud mendapatkan persentase yang cukup rendah, namun tingkat kerugian yang ditimbulkan cukup tinggi yaitu sebesar \$975.000 pada tahun 2016. Hal ini membuktikan bahwa Financial Statement Fraud perlu mendapatkan penanganan secara serius agar tidak menimbulkan 
tingkat kerugian yang lebih tinggi. Begitu banyaknya jenis-jenis tindakan kecurangan, tentu banyak hal yang dapat memicu terjadinya tindakan kecurangan tersebut. Beberapa hal yang dapat memicu terjadinya kecurangan antara lain seperti tekanan, kesempatan dan rasionalisasi yang ada.

Manipulasi laporan keuangan digunukan untuk menghasilkan keuntungan yang tetapi dengan cara yang tidak sesuai koridor bahkan bertentangan dengan moral. Sebagaimana yang kita ketahui laporan keuangan merupakan catatan informasi keuangan suatu perusahaan yang dapat digunakan untuk menggambarkan bagaimana kondisi perusahaan tersebut. Tetapi sebesar dan sepopuler bagaimanapun suatu perusahaan, selalu saja ada penyelewengan dari pihak terkait, seperti yang terjadi baru-baru ini diperusahaan Garuda Indonesia yang melakukan manipulasi laporan keuangan (Yusuf, 2020).

Berbagai upaya pun dapat dilakukan untuk memerangi terjadinya kecurangan laporan keuangan. Salah satunya ialah melakukan upaya pendeteksian melalui laporan keuangan perusahaan dengan menerapkan analisis laporan keuangan untuk mengidentifikasi adanya indikasi (red flags) atas kecurangan laporan keuangan.

Analisis laporan keuangan merupakan suatu prosedur analisis atas pos-pos dalam laporan keuangan untuk memahami dan menilai kondisi perusahaan yang terefleksikan dalam laporan keuangan, yang mana hal ini dapat dilakukan dengan bermacam-macam teknik dan untuk bermacam-macam tujuan. Terkait dengan kecurangan laporan keuangan, teknik analisis laporan keuangan dapat digunakan untuk mengidentifikasi adanya indikasi berupa keganjilan hubungan antar item dalam laporan keuangan akibat adanya kecurangan. Kombinasi atas penerapan teknik analisis laporan keuangan dalam pemeriksaan kecurangan laporan keuangan dapat memberikan suatu dasar yang logis dalam upaya pendeteksian kecurangan laporan keuangan.

Beberapa penelitian mengenai deteksi kecurangan laporan keuangan telah dilaksanakan (Christy \& Stephanus, 2018) mengungkapkan bahwa persentases perusahaan perbankan yang tergolong sebagai non manipulator pada tahun 2014 sebesar 4,76\%, tahun 2015 38,1\% dan tahun 2016 47,6\%. Persentase perusahaan perbankan yang tergolong sebagai grey company pada tahun 2014 sebesar 38,1\%, tahun 2015 50\% dan tahun 2016 45,2\%. Persentases perusahaan perbankan yang tergolong sebagai manipulator pada tahun 2014 sebesar 57,1\%, tahun 2015 11,9\% dan tahun 2016 7,14\%.

Selanjutnya (Darmawan, 2016) menunjukkan bahwa 14 perusahaan manufaktur di BEI tahun 2013-2014 tergolong manipulator terdapat 4,6\%, non manipulator $64,8 \%$, tidak tergolong manipulator atau non manipulator 30,7\%, masuk indeks parameter manipulator DSRI 4,5\%, masuk indeks parameter manipulator GMI 31,8\%, masuk indeks parameter manipulator AQI 18,2\%, masuk indeks parameter manipulator SGI 3,4\% dan masuk indeks parameter manipulator TATA $19,3 \%$.

Serta (Kurnianingsih \& Siregar, 2019) menunjukkan Perusahaan konsumsi yang terdaftar di Bursa Efek Indonesia yang tergolong manipulator pada tahun 2016 sebanyak 2 perusahaan atau 9,52\% dan tahun 2017 sebanyak 2 perusahaan atau 9,52\%. Selama tahun 
2013-2017 perusahaan konsumsi yang tergolong sebagai manipulator mengalami peningkatan dan penurunan (adanya fluktuasi). Dan perusahaan konsumsi yang terdaftar di Bursa Efek Indonesia yang tergolong non manipulator pada tahun 2016 sebanyak 19 perusahaan atau 90, 48\% dan tahun 2017 sebanyak 17 perusahaan atau 80,95\% tergolong sebagai non manipulator mengalami peningkatan dan penurunan (adanya fluktuasi). Serta Perusahaan konsumsi yang terdaftar di Bursa Efek Indonesia yang tergolong grey company pada tahun 2016 tidak terdapat perusahaan yang tergolong grey company dan tahun 2017 sebanyak 2 perusahaan atau 9,52\%. Selama tahun 2013-2017 perusahaan konsumsi yang tergolong sebagai grey company mengalami peningkatan dan penurunan (adanya fluktuasi).

Penelitian ini merupakan replikasi (Christy \& Stephanus, 2018), adapun perbedaan penelitian ini dengan penelitian sebelumnya yaitu sampel penelitian ini menggunakan seluruh perusahaan yang terdaftar di Bursa Efek Indonesia tahun 2019. Dengan menggunakn sampel seluruh sector yang terdaftar di BEI diharapkan penelitian ini dapat memberikan gambaran tentang kecurangan laporan keuangan dengan menggunakan Beneish M-Score.

\section{TINJAUAN PUSTAKA}

\section{Beneish M-Score}

Terkait dengan kecurangan laporan keuangan, teknik analisis laporan keuangan dapat digunakan untuk mengidentifikasi adanya indikasi berupa keganjilan hubungan antar item dalam laporan keuangan akibat adanya kecurangan. Kombinasi atas penerapan teknik analisis laporan keuangan dalam pemeriksaan kecurangan laporan keuangan dapat memberikan suatu dasar yang logis dalam upaya pendeteksian kecurangan laporan keuangan (Kartikasari \& Irianto, 2010).

Beneish M-Score adalah suatu teknik analisis laporan keuangan dapat diterapkan untuk mendeteksi kecurangan laporan keuangan berupa manipulasi laba --earning overstatement. Pernyataan ini telah dijawab oleh Messod D. Beneish, seorang profesor di Indiana University yang melakukan penelitian atas perbedaan kuantitaif antara perusahaan yang teridentifikasi telah melakukan manipulasi laba dan perusahaan yang teridentifikasi tidak melakukan manipulasi laba. Ia menggunakan data keuangan perusahaan lalu menghitung rasio keuangan perusahaan tersebut untuk mengetahui apakah terjadi perubahan rasio akibat atas adanya manipulasi atau untuk mengetahui apakah terdapat kondisi yang dapat mendorong adanya manipulasi tersebut.

Beneish mengungkapkan bahwa pada umumnya manipulasi laba ditunjukkan dengan peningkatan atas pendapatan atau penurunan atas beban perusahaan secara signifikan dari suatu tahun (t) ke tahun sebelumnya ( $\mathrm{t}-1)$. Berdasarkan hal tersebut, Beneish mengembangkan suatu rasio terkait dengan perubahan aset dan pertumbuhan penjualan yang dirumuskan dalam M-Score yaitu skor yang merefleksikan terjadinya manipulasi laba. Hasil penelitian Beneish menunjukkan bahwa terdapat hubungan antara manipulasi laba dengan beberapa rasio kunci tersebut. 
Menurut (Christy \& Stephanus, 2018) menjelaskan beberapa rasio yang digunakan antara lain: 1) Days Sales Receivables Index (DSRI); (2) Gross Margin Index (GMI); (3) Asset Quality Index (AQI); (4) Sales Growth Index (SGI); (5) Total Accrual to Total Assets Index (TATA) yang selanjutnya diformulasikan ke dalam M-Score --manipulation score.

\section{METODE PENELITIAN}

\section{Jenis Penelitian}

Metode yang digunakan dalam penelitian ini adalah metode deskriptif dan pendekatan yang digunakan dalam penelitian ini adalah pendekatan kuantitatif. Penelitian deskriptif (descriptive research) adalah suatu metode penelitian yang ditujukan untuk menggambarkan fenomena-fenomena yang ada, yang berlangsung pada saat ini atau saat yang lampau.

\section{Definisi Operasional}

Variabel dependen dalam penelitian ini adalah Financial Statement Fraud yang diukur dengan Beneish M-Score. Menurut Aris et. al, (2013) Beneish M-Score adalah model matematika yang merumuskan beberapa rasio analisis dan terdiri dari delapan variabel untuk mengidentifikasi terjadinya penipuan keuangan atau kecenderungan untuk terlibat dalam mendapatkan manipulasi. Dan telah diperoleh hasil perhitungan Beneish M- Score yang telah kekal (robust), dengan indikasi jika lebih dari -2,22 diklasifikasikan sebagai perusahaan manipulator, bila kurang dari -2,22 diklasifikasikan sebagai perusahaan non-manipulator.

Menurut Beneish (1999) delapan variabel yang digunakan dalam Beneish M-Score diantaranya:

1. Days' Sales in Receivables Index (DSRI)

Jumlah yang besar dalam days sales in receivables dapat berarti akibat dari perubahan kebijakan kredit untuk memacu penjualan dalam menghadapi persaingan yang meningkat, tetapi peningkatan yang tidak proporsional dalam piutang juga dapat dipengaruhi oleh inflasi. Jadi, peningkatan besar dalam DSRI

\section{Gross Margin Index (GMI)}

$$
D S R I=\frac{\text { Receivables } t \div \text { Sales } t}{\text { Receivable } t-1 \div \text { Sales } t-1}
$$

Ketika GMI lebih besar dari 1, margin kotor telah memburuk. Lev dan Thiagarajan dalam Beneish (1999) menyatakan bahwa margin kotor yang buruk adalah sinyal negatif tentang prospek perusahaan. Jadi jika perusahaan dengan prospek yang buruk lebih memungkinkan untuk terlibat dalam manipulasi laba. Rumus Gross Margin Index (GMI) adalah sebagai berikut::

3. Asset Quality Index (AQI)

$$
G M I=\frac{\text { Sales } \left._{t-1}-\text { COGS }_{t-1}\right) \div \text { Sales }_{t-1}}{\left(\text { Sales }_{t}-\text { COGS }_{t}\right) \div \text { Sales }_{t}}
$$

Jika nilai AQI lebih besar dari 1 mengindikasikan perusahaan memiliki kompetensi untuk meningkatkan biaya tangguhan atau meningkatkan aset tidak berwujud dan memanipulasi pendapatan. Jadi semakin besar AQI, mengindikasikan penurunan kualitas aset, 
semakin besar kemungkinan manipulasi pendapatan. Rumus Asset Quality Index (AQI) adalah sebagai berikut:

$$
A Q I=\frac{\text { Current Assets }+ \text { Property, plant, Equipment }}{\text { Total Assets }}
$$

4. Sales Growth Index (SGI)

Hasil yang lebih besar dari 1 mengindikasikan bahwa penjualan meningkat dari tahun sebelumnya. SGI bukan merupakan indikasi manipulasi pendapatan, tetapi perusahaan yang mengalami pertumbuhan penjualan lebih cenderung untuk melakukan manipulasi pendapatan. Rumus Sales Growth Index (SGI) adalah sebagai berikut:

5. Total Acrual to Total Assets (TATA)

$$
S G I=\frac{\text { Sales }_{t}}{\text { Sales }_{t-1}}
$$

Akrual memberikan kesempatan secara konsisten untuk melakukan kecurangan. Jadi, hasil positif yang lebih besar berkaitan dengan potensi manipulasi laba. Rumus Total Accruals to Total Assets (TATA) adalah sebagai berikut:

$$
T A T A=\frac{\text { Income from Operating }_{t}-\text { Cash Flow from Operating }_{t}}{\text { Total Assets }}
$$

\section{Subjek Penelitian}

Sampel penelitian ini adalah perusahaan sector penghasil bahan baku dan sector manufaktur yang terdaftar di Bursa Efek Indonesia (BEI) tahun 20019, dengan ketentuan sebagai berikut:

1. Terdaftar padda Bursa Efek Indonesia tahun 2019.

2. Memiliki laporan keuangan yang dapat diakses.

3. Laporan keuangan menggunakan mata uang Rupiah (Rp).

\section{Analisis Data}

Dalam penelitian ini, peneliti menggunakan Beneish M-Score dengan teknik indeks analisis rasio yang digunakan untuk memprediksi adanya indikasi kecurangan terhadap laporan keuangan perusahaan, sehingga dapat menjadi acuan untuk menentukan perusahaan yang tergolong manipulator, non manipulator atau grey company. Dengan menggunakan lima indeks indikator Beneish perusahaan-perusahaan diklasifikasikan sebagai perusahaan non manipulator, grey company dan manipulator. Perusahaan dengan Beneish M-Score lebih tinggi memiliki kemungkinan lebih untuk melakukan fraud. Beneish M-Score merupakan model probabilistik, sehingga tidak akan mendeteksi fraud dengan ketepatan $100 \%$.

a) Menghitung Beneish M-Score perusahaan sesuai dengan rumus masing Membandingkan Index Hitung dengan menggunakan Index parameter.

1. Days Sales in Receivable Index (DSRI)

Indeks Parameter Days Sales in Receivable Index (DSRI)

\begin{tabular}{lll}
\hline No & Index & Keterangan \\
\hline 1 & $\leq 1,031$ & Non Manipulator \\
2 & $1,031>$ indek $\leq 1,465$ & Grey Company \\
3 & $\geq 1,465$ & Manipulator \\
\hline
\end{tabular}


2. Gross Margin Index (GMI)

Index Parameter Gross Margin Index (GMI)

\begin{tabular}{lll}
\hline No & Index & Keterangan \\
\hline 1 & $\leq 1,041$ & Non Manipulator \\
2 & $1,041>$ index $<1,465$ & Grey Company \\
3 & $\geq 1,465$ & Manipulator \\
\hline
\end{tabular}

3. Asset Quality Index (AQI)

\begin{tabular}{lll} 
& \multicolumn{2}{l}{ Indeks Parameter Asset Quality Index (AQI) } \\
\hline No & Index & Keterangan \\
\hline 1 & $\leq 1,039$ & Non Manipulator \\
2 & $1,039>$ index $<1,254$ & Grey Company \\
3 & $>1,254$ & Manipulator \\
\hline
\end{tabular}

4. Sales Growth Indx (SGI)

Indeks Parameter Sales Growth Index (SGI)

\begin{tabular}{lll}
\hline No & Index & Keterangan \\
\hline 1 & $\leq 1,134$ & Non Manipulator \\
2 & $1,134>$ index $<1,606$ & Grey Company \\
3 & $\geq 1,607$ & Manipulator \\
\hline
\end{tabular}

5. Total Accruals to Total Assets (TATA)

Indeks Parameter TATA

\begin{tabular}{lll}
\hline No & Index & Keterangan \\
\hline 1 & $\leq 0,018$ & Non Manipulator \\
2 & $0,018>$ index $<0,031$ & Grey Company \\
3 & $\geq 0,031$ & Manipulator \\
\hline
\end{tabular}

Menentukan perusahaan yang tergolong manipulator atau nonmanipulator dengan kriteria sebagai berikut. (Darmawan, 2016)

a) Perusahaan yang memiliki $\geq 3$ indeks hitung yang sesuai dengan indeks parameter yang menyatakan manipulator, tergolong ke dalam manipulator.

b) Perusahaan yang memiliki $\geq 3$ indeks hitung yang sesuai dengan indeks parameter yang menyatakan nonmanipulator, tergolong ke dalam manipulator.

c) Perusahaan yang memiliki $\geq 3$ indeks hitung yang sesuai dengan indeks parameter yang menyatakan grey company, dan indeks hitung yang tidak memenuhi 2 kriteria penggolongan manipulator dan nonmanipulator dapat digolongkan sebagai grey company

Menghitung jumlah persentase dari perusahaan yang tergolong manipulator, non manipulator atau grey company (Fabelli, 2011) 


\section{Deskripsi Objek Penelitian}

Gambaran umum objek penelitian menyajikan prosedur pemilihan sampel dan kelompok perusahaan yang menjadi populasi dari penelitian ini. Objek penelitian ini adalah sector industry bahan baku dan sector manufaktur yang terdaftar di Bursa Efek Indonesia tahun 2019. Dengan ketentuan sebagai berikut:

1. Terdaftar padda Bursa Efek Indonesia tahun 2019.

2. Memiliki laporan keuangan yang dapat diakses.

3. Laporan keuangan menggunakan mata uang Rupiah (Rp).

Adapun data yang digunakan adalah data sekunder yang berasal dari laporan keuangan tahun 2019 melalui situs resmi Bursa Efek Indonesia pada alamat website www.idx.co.id dibawah iini menyajikan tahapan seleksi sampel berdasarkan kriteria yang telah ditetapkan:

Tahapan seleksi sampel dengan kriteria

\begin{tabular}{|l|c|}
\hline \multicolumn{1}{|c|}{ Keterangan } & Jumlah \\
\hline $\begin{array}{l}\text { perusahaan sektor penghasil bahan baku } \\
\text { dan sektor manufaktur yang terdaftar di } \\
\text { BEI tahun 2019 }\end{array}$ & \\
\hline $\begin{array}{l}\text { Perusahaan yang laporan keuangannya } \\
\text { tidak dapat diakses }\end{array}$ & 250 \\
\hline $\begin{array}{l}\text { Perusahaan yang menggunakan mata } \\
\text { uang selain Rupiah (Rp) }\end{array}$ & 51 \\
\hline Sampel Penelitian & 178 \\
\hline
\end{tabular}

berdasarkan dapat dilihat bahwa jumlah perusahaan yang dapat dijadikan sampel pada penelitian ini sebanyak 178 perusahaan .

\section{HASIL PENELITIAN}

Penelitian ini bertujuan untuk mengetahui perusahaan yang tergolong manipulators, non manipulators, dan grey company. Objek yang diteliti adalah perusahaan industry bahan baku dan manufaktur yang terdaftar di BEI tahun 2019. Berdasarkan kriteria sampel yang ditentukan, diperoleh 178 perusahaan yang sesuai dengan kriteria.

perhitungan Beneish M-Score untuk mengetahui apakah perusahaan tergolong manipulators atau non manipulators. Langkah-langkah yang dilakukan untuk menentukan apakah perusahaan tergolong manipulators, non manipulators dan Grey Company.

Ringkasan Penentuan Kategori Non Manipulator, Grey Company dan Manipulator

\begin{tabular}{|l|r|r|r|r|r}
\hline \multicolumn{1}{|c|}{ Kelompok } & \multicolumn{1}{c|}{ DSRI } & \multicolumn{1}{c|}{ GMI } & \multicolumn{1}{c|}{ AQI } & \multicolumn{1}{c|}{ SGI } & \multicolumn{1}{c}{ TATA } \\
\hline Non Manipulator & 98 & 115 & 104 & 142 & 178 \\
\hline Grey Company & 56 & 49 & 13 & 30 & 0 \\
\hline Manipulator & 22 & 12 & 61 & 5 & 0 \\
\hline
\end{tabular}

Berdasarkan table diatas ditunjukkan bahwa dari rasio DSRI kelompok Non Manipulator 98 perusahaan; Grey Company 56 Perusahaan dan 22 perusahaan termasuk 
kelompok manipulator. Berikutnya dari rasio GMI menunjukkan bahwa 115 perusahaan termasuk Non-Manipulator; 49 perusahaan Grey Company dan 12 perusahaan termasuk kelompok Manipulator.

Rasio berikutnya adalah rasio AQI menunjukkan 104 perusahaan termasuk perusahaan Non-Manipulator; 13 perusahaan Grey Company dan 61 perusahaan termasuk Manipulator. Selanjutnya berdasrkan rasio TATA menunjukkan bahwa 142 perusahaan termasuk NonManipulator; 30 perusahaan Grey Company dan 5 perusahaan termasuk kelompok Manipulator.

Rasio terakhir adalah rasio TATA yaitu rasio perubahan modal kerja (selain kas dan piutang pajak dikurangi depresiasi) terhadap total asset. Menunjukkan bahwa semua perusahaan sampel yaitu178 perusahaan termasuk Non-Manipulator;

\section{Pembahasan}

Terdapat beberapa indikator yang menggolongkan perusahaan sebagai kategori manipulators. Seperti pada indikator Assets Quality Index (AQI) dihasilkan 61 perusahaan sampel tergolong sebagai manipulators. Hal ini menunjukkan bahwa perusahaan tersebut memiliki indikasi secara potensial melakukan peningkatan pengendalian biaya. Perusahaan yang melakukan kecurangan laporan keuangan dapat merugikan berbagai pihak yang terlibat secara langsung maupun tidak langsung dengan perusahaan. Bagi investor kecurangan tersebut dapat meningkatkan resiko rendahnya tingkat pengembalian atas investasi yang sudah ditanamkan pada perusahaan. bagi kreditor kecurangan ini dapat meningkatkan resiko gagal bayar atas pinjaman yang telah diberikan kepada perusahaan.

Perusahaan yang tergolong sebagai perusahaan non-manipulators mencerminkan bahwa perusahaan memiliki komitmen untuk melindungi kepentingan pengguna laporan keuangan dengan tidak menyajikan laporan keuangan yang dimanipulasi. Bagi kreditor dan investor, hal ini menjadi sinyal positif untuk lebih mudah dalam menentukan keputusan untuk memberikan kredit dan investasi pada perusahaan. Investor dan kreditor dapat meningkatkan kepercayaan terhadap perusahaan yang tergolong sebagai non manipulators karena tidak ada indikasi dalam melakukan kecurangan laporan keuangan. Hal ini bisa menurunkan resiko rendahnya tingkat pengembalian modal dan resiko gagal bayar atas investasi dan pinjaman yang mereka keluarkan kepada perusahaan.

Perusahaan sampel yang tergolong sebagai grey company digolongkan sebagai perusahaan manipulators maupun non manipulators karena kriteria dari kedua kategori tidak terpenuhi. Namun terdapat beberapa variabel yang menunjukkan perusahaan tergolong sebagai manipulators namun jumlahnya tidak signifikan sehingga secara keseluruhan tidak dinyatakan sebagai perusahaan manipulators. Bagi investor dan kreditor hendaknya lebih berhati-hati terhadap perusahaan dengan kategori ini karena memiliki potensi dalam melakukan manipulasi laporan keuangan.

\section{SIMPULAN}

Berdasarkan analisis dan pembahasan yang telah disampaikan pada bab sebelumnya maka dapat diambil kesimpulan sebagai berikut: 
Analisis kecurangan laporan keuangan menggunakan Beneish M- Score Model terdapat 2 perusahaan yang memiliki kategori manipulator pada 3 katagori yang diukur. Perusahaan sampel menunjukkan bahwa ada 2 perusahaan yang tergolong sebagai manipulators. Sedangkan yang lainnya masuk kategori grey company dan non manipulator. Perusahaan non manipulator menunjukkan perusahaan memiliki komitmen untuk menyajikan laporan keuangan yang tidak menyesatkan para stakeholder yang memiliki kepentingan terhadap laporan keuangan perusahaan. Sedangkan perusahaan grey company memiliki indikasi melakukan kecurangan laporan keuangan namun dalam jumlah yang tidak signifikan.

\section{Saran}

Penelitian ini menunjukkan alat analisis dalam pendeteksian kecurangan laporan keuangan menggunakan indeks atau rasio yang terdapat dalam laporan keuangan. Hasil pendeteksian yang dilakukan di perusahaan menunjukkan bahwa terdapat 2 perusahaan yang tergolong sebagai manipulators. Namun beberapa sampel penelitian tergolong sebagai grey company. Hal ini sebagai indikasi terdapat kecenderungan melakukan manipulasi namun jumlahnya tidak signifikan. Implikasi dalam penelitian ini yaitu agar perusahaan menyajikan laporan keuangan sesuai ketentuan yang berlaku agar tidak menyesatkan pengguna laporan keuangan.

\section{DAFTAR PUSTAKA}

Christy, Y. E., \& Stephanus, D. S. (2018, Maret 1). Pendeteksian Kecurangan Laporan Keuangan dengan Beneish M-Score Pada Perusahaan Perbankan Terbuka. Jurnal Akuntansi Bisnis, 16(1), 19 - 41.

Yusuf, A. Y. (2020, Januari 1). Manipulasi Laporan Keuangan . Retrieved Februari 18, 2020, from makasar.terkini.id: https://makassar.terkini.id/manipulasi-laporan-keuangan/

Darmawan, A. Z. (2016). Analisis Beneish Ratio Index Untuk Mendeteksi Kecurangan Laporan Keuangan. Jurnal Profita, 6.

Kurnianingsih, H. T., \& Siregar, M. A. (2019). Metode Beneish Ratio Index dalam Pendeteksian Financial Statement Fraud (Studi Kasus Perusahaan Konsumsi di Bursa Efek Indonesia). Jurnal Riset Akuntansi Multiparadigma (JRAM), 6(1).

Baridwan, Z. (1997). Intermediate Accounting. Yogyakarta: BPFE.

Putri, A. (2012). Kajian: Fraud (Kecurangan) Laporan Keuangan. JRAK: Jurnal Riset \& Komputerisasi Akuntansi.

Kartikasari, R. N., \& Irianto, G. (2010, Agustus). Penerapan Model Beneish (1999) dan Model Altman (2000) dalam Pendeteksian Kecurangan Laporan Keuangan. Jurnal Akuntansi Multiparadigma, 1(2). 
Christy, Y. E., \& Stephanus, D. S. (2018, Maret). Pendeteksian Kecurangan Laporan Keuangan dengan Beneish M-Score pada Perusahaan Perbankan Terbuka. Jurnal Akuntansi Bisnis, 16(1). 